\title{
Mast cell changes in experimental diabetes: focus on attenuation of allergic events
}

\author{
Vinicius F Carvalho, Emiliano 0 Barreto, Renato SB Cordeiro, Vincent Lagente*, \\ Marco A Martins, Patrícia MR e Silva/ ${ }^{+}$
}

Laboratório de Inflamação, Departamento de Fisiologia e Farmacodinâmica, Instituto Oswaldo Cruz-Fiocruz, Av. Brasil 4365, 21040-900 Rio de Janeiro, RJ, Brasil *Laboratoire de Pharmacodynamie et de Pharmacologie Moléculaire, INSERM U620,

Université de Rennes, Rennes, France

The prevalence of atopic diseases and diabetes is increasing worldwide though the concurrence of these pathologies in individual patients is found less frequent than it would be predicted. Moreover, co-existence of diabetes and allergy is generally marked by attenuation of their respective symptoms, and effective treatment of one disease exacerbates the other. This review gives an update of the state-of-the-art concerning the intercurrence of allergy and diabetes, particularly focusing on the consequences to the allergen-evoked vascular and cellular changes. It is proposed that the reduction in mast cell numbers and reactivity may be a pivotal mechanism behind the mutual exclusion phenomenon.

Key words: diabetes - allergy - mast cells - glucocorticoids

Diabetes mellitus represents a heterogeneous group of disorders which have hyperglycemia as a common feature (Tisch \& McDevitt 1996, Bell \& Polonsky 2001). Although diabetes has long been considered a disease of minor significance, it is considered now as one of the main threats to human health in 21 st century. Great changes in the human environment, behavior, and lifestyle resulted in the raising rates of diabetes (Zimmet et al. 2001). According to the World Health Organization, the existence of different clinical presentations and genetic and environmental etiologic factors have led to five types of diabetes recognized and termed as i) insulin-dependent diabetes mellitus (IDDM, type 1 diabetes), ii) non-insulindependent diabetes mellitus (NIDDM, type 1 diabetes), iii) gestational-related diabetes (GDM), iv) malnutritionrelated diabetes, and v) other types (Muir et al. 1992, Atkinson \& Maclaren 1994, Hoet \& Tripathy 1996, Bell \& Polonsky 2001).

Diabetes is consequence of defects in insulin secretion, insulin action or both, which is translated into abnormalities of carbohydrate, fat and protein metabolism, resulting in hyperglycemia (Klip et al. 1992, Taskinen et al. 1996) Symptoms of chronic hyperglycemia include polyuria, polydipsia, and polyphagia as well as weight loss. Although varying among patients, long term complications of diabetes can also include changes in arteries (atherosclerosis), basement membranes of small vessels (microangiopathy), kidneys (nephropathy), retina (retinopathy), and nerves (neuropathy) (Vlassara et al. 1984, Yabe-Nishimura 1998, Brownlee 2001).

Financial support: CNPq, Faperj, Papes III/Fiocruz ${ }^{+}$Corresponding author. E-mail: patmar@ioc.fiocruz.br Received 8 November 2004

Accepted 30 December 2004
It has generally been stated that uncontrolled type 1 diabetic patients are more susceptible to bacterial and fungal infections than normal controls, though the cause has not yet been determined (Larkin et al. 1985). In order to investigate this point, experimental models of diabetes have been developed from which chemical induction with alloxan has been the most widely used (Rerup 1970). Administration of alloxan to different animals produces, via necrosis of the islets, several features common to those observed in human diabetes (Lukens 1948, Gaulton et al. 1985, Quan et al. 2001). There is some evidence that diabetics present a deficiency in mounting an inflammatory response, probably associated with severe reduction in insulin secretion rather than increased blood glucose levels (Garcia Leme et al. 1973, Garcia Leme \& Farsky 1993). This is still a controversial point as other investigators have suggested a direct correlation between hyperglycemia and the incidence of infection in diabetic patients (Rayfield et al. 1982). A number of studies shows that diabetic animals present a decreased response to intradermally administered bradykinin and vasoactive amines as well as swelling induced by dextran, carrageenan, and cellulose sulphate, indicating alteration in the microcirculatory reactivity (Garcia-Leme et al. 1974, Fortes et al. 1984, Akamine et al. 2003). Moreover, neutrophils from diabetics have also been shown to present functional abnormalities such as less phagocytizing capacity (Wertman \& Henney 1962) and chemotactic responses (Mowat \& Baum 1971, Fortes et al. 1991, Mello et al. 1992), which might be extended to other inflammatory cells as those involved in allergic processes.

\section{Diabetes vs allergy}

It is noteworthy that allergic disorders, including asthma, atopic dermatitis and eczema, have an uncommon occurrence in diabetic patients (Tinkelman \& King 1979, Bottini \& Fontana 1999, Douek et al. 1999, Olesen et al. 2001, Cardwell et al. 2003), though the reason for this mutual 
exclusion is still debatable. The possibility does exist that the Th1/Th2 paradigm could be a potential explanation. As already stated, autoimmune diseases such as type-1 diabetes involves a cellular T-helper response characteristic of the Th1 phenotype, and allergic diseases are associated with Th2 phenotype (Romagnani 1991, Abbas et al. 1996). There is substantial evidence that Th1 and Th2 pathways each control a unique group of immune responses, by means of differences in cytokines produced and transcription factors involved, promoting the development of cells of the same subset while suppressing the expansion and effector cells of the other subset (Rapoport et al. 1993). Thus it is reasonable to speculate that an imbalance between the Th1/Th2 subtypes might contribute to the negative association between type-1 diabetes and atopic diseases. In line with this idea and considering IL-4 as a major cytokine to induce differentiation of naive T-cell precursors into Th2 cells and B cell switch to produce the immunoglobulin E, a study with multiplex Causasian families shows significant evidence of linkage and association of the ILAR gene with type 1 diabetes (Mirel et al. 2002). The existence of a halotype of IL-4R gene, which appears to be protective and associated with individuals exhibiting the strongest risk for type 1 diabetes, has been identified. Additionally, it has been reported that peripheral and thymic $\mathrm{T}$ cells from spontaneous nonobese diabetic (NOD) mice (Rapoport et al. 1993) as well as from mice rendered diabetic by sptreptozotocin (Wood et al. 1999) significantly secrete less amount of IL-2 and IL-4 when compared with cells from their respective controls. Moreover, exogenously added rlL-4 not only did it restore the NOD thymic and peripheral $\mathrm{T}$ cell proliferative responses but also protects NOD mice from developing diabetes (Rapoport et al. 1993).

\section{Down-regulation of allergic inflammation in experimental diabetes}

While investigating the reason why clinical asthma appeared less severe when diabetes mellitus was superimposed, Vianna and Garcia-Leme (1995) demonstrated that compared with controls, animals that were turned diabetic after alloxan injection presented a marked decrease in the number of cells recovered from bronchoalveolar lavage after antigen challenge (Vianna \& Garcia-Leme 1995). In accordance with the above observation, using the model of pleural allergic response in rats (Lima et al. 1990, 1991, Silva et al. 1992), we found that sensitized animals rendered diabetic after alloxan reacted to antigenic challenge with 50\% reduction in the number of eosinophils recruited to the pleural cavity (Diaz et al. 1996, 1997). The less pronounced eosinophil accumulation did not relate to an intrinsic cell locomotor abnormality since eosinophils from diabetic rats presented similar chemotactic responses in vitro as compared to matching controls (Diaz et al. 1996). Moreover, antigen-induced protein leakage (de Oliveira Barreto et al. 2003) as well as neutrophil infiltration (unpublished data) were also clearly suppressed in diabetic sensitized rats. Interestingly, we showed that suppression of allergic responses in diabetic rats well correlated with a selective and time-dependent reduction in the number of pleural mast cells $(50 \% \pm 2.2 \%, \mathrm{p}<0.01$; mean \pm SEM), while other leucocytes were not altered. As compared to naive animals, the reduction in mast cell numbers was first noted $48 \mathrm{~h}$ following alloxan administration and remained unaltered for at least 60 days (Diaz et al. 1996). Furthermore, the amount of histamine stored in diabetic mast cell granules was not different from that found in controls, clearly indicating that alloxan induced a decrease in the number of mast cells rather than their degranulation (Diaz et al. 1996, de Oliveira Barreto et al. 2003). Altogether these findings suggested that down-regulation of mast cells could be responsible for at least part of refractoriness of diabetic animals to antigen challenge. Since mast cells played a critical role not only in eosinophil recruitment but also in other key features of the allergic inflammatory response (Metcalfe et al. 1997), we further evaluated how diabetes-associated mast cell disturbance could effect the suppression of allergen-mediated inflammation under diabetic conditions. The reconstitution of the pleural mast cell population in diabetic animals, by means of adoptive transfer system, restored the antigen-induced plasma leakage (de Oliveira Barreto et al. 2003). Additionally, the transfer of diabetic sensitized mast cells to normal animals caused a lower pleural exudatory response compared to the response produced by nondiabetic mast cells, indicating that not only the number of mast cells and also their reactivity were significantly reduced in experimental diabetes. In fact, purified mast cells from diabetic rats were hyporesponssive to antigen and compound $48 / 80$ stimulation in vitro as attested by histamine release (de Oliveira Barreto et al. 2003), in direct correlation with increase in the intracellular levels of cAMP (Barreto et al. 2004). This was an indicative that augmentation in the amount of cAMP nucleotide could be accounted for by the refractoriness of mast cells under diabetic conditions.

The resistance of diabetic animals to allergen provocation was also extended to the condition of systemic anaphylaxis (Ganley 1962, Dhar et al. 1967), when a substantial reduction in mortality rate, intestinal haemorrhage and plasmatic levels of histamine were evidenced (Carvalho et al. 2003). Moreover, in the case of diabetic animals fragments of trachea, skin, and intestine showed refractoriness to the antigen challenge in vitro (de Oliveira Barreto et al. 2003), providing evidence that similarly to what was noted in the case of free mast cells, those located in tissues seemed to be negatively regulated in diabetes. In addition, the diabetic state was also shown to affect the sensitization stage of the anaphylactic reaction, since the augmentation in total and ovalbumin specific serum IgE levels was suppressed in diabetic sensitized rats (Carvalho et al. 2003). Coherently, Ptak et al. (1983) demonstrated that immune cells recovered from spleen and lymph nodes when transferred from naive into diabetic mice lost their ability to form $\operatorname{IgE}$, whereas the immune cell suspensions from diabetic animals regained the capacity to generate IgE upon transfer to normal recipients (Ptak et al. 1983). These findings suggested that a soluble factor present in the blood circulation of diabetic mice interfered directly or indirectly with IgE-producing cells. 


\section{Balance between steroid and insulin levels in diabetes}

Hyperactivity of the hypothalamic-pituitary-adrenal axis with consequent hypercortisolism was frequently observed in patients with type 1 and type 2 diabetes (Cameron et al. 1984, Roy et al. 1990, 1998, Chan et al. 2002), and seemed to be associated with increased expression of hypothalamic corticotrophin-releasing hormone (CRH) mRNA (Chan et al. 2003). We described an increase in the adrenal-gland/body weight rate in parallel to an elevation in serum corticosterone levels following diabetes caused by alloxan treatment in rats. The reduction of mast cell number and reactivity as well as of antigen-induced IgE formation, noted in alloxan diabetes, was reversed by surgical bilateral adrenalectomy and by treatment with the steroid blocker RU 486 (Diaz et al. 2001, Carvalho et al. 2003, Barreto et al. unpub. data), indicating a causative link between the negative regulation of mast cell-IgE system and enhanced serum glucocorticoid levels. These findings were consistent with previous reports which had demonstrated the effect of glucocorticoids in inducing depletion of mast cells in different body sites including skin, lung, and intestine (Pipkorn et al. 1989, Goldsmith et al. 1990, Finotto et al. 1997). Glucocorticoids were shown to have their anti-inflammatory activity due to inhibition of gene transcription, resulting in a smaller production of a wide range of effectors such as cytokines (Schleimer 1993, Barnes 2004), including the stem cell factor (SCF) (Finotto et al. 1997), IL-3 and IL-4 (Braun et al. 1997). Thus, the inhibition by glucocorticoids of the cytokine production by cells of the microenvironment space might be a plausible explanation for mast cell depletion noted in diabetes.

As opposed to glucocorticoids, insulin is considered a pro-inflammatory hormone (Strauss 1984) capable of sensitizing rats to the anaphylactoid reaction caused by dextran, and restoring the reactivity to antigen challenge when given to diabetic rats (Diaz et al. 1996). In fact, we have noted that treatment with insulin restores the baseline levels of mast cells in the pleural cavity of diabetic rats (Diaz et al. 2001), a phenomenon which may be explained by its known proliferative activity verified in different cell systems (Strauss 1984). Similar findings obtained by Cavalher-Machado et al. (2004), show that insulin might also modulate mast cell degranulation at the early-phase response to antigen provocation, which represents an alternative insight for a better understanding of the mechanisms accounted for the decreased risk of asthma among type-1 diabetic patients (Cavalher-Machado et al. 2004). In this context, our group has reported that treatment of alloxinated rats with insulin impaired the increase in the systemic levels of corticosterone, indicating that insulin can directly control glucocorticoid secretion (Diaz et al. 2001). These data are in line with those of Meehan et al. (1988) who reported that insulin, when injected into diabetic animals by intracerebro ventricular via, impaired the increase in the systemic levels of glucocorticoids (Meehan et al. 1988). Likewise, glucocorticoids are shown to be effective in inhibiting insulin secretion by pancreatic $\beta$ cells (Ludvik et al. 1993) and in inducing tolerance to insulin in diabetic patients (Isoniemi et al. 1993). Thus, our findings support the concept that insulin and glucocorticoids have antagonistic effects on different biological systems and can also regulate the level of each other.

\section{Conclusion}

The focus of this review has been the decline in incidence of atopic diseases in diabetic individuals and viceversa. There is evidence demonstrating that the mutual antagonistic effect of Th1 and Th2 cells can contribute to negative association between allergy and diabetes, possibly by means of selective cytokine networks. Additionally, we also provide evidence that a defective response of IgE-mast cell system, in close relationship with increased glucocorticoid levels, is implicated in the refractoriness to allergen challenge detected in diabetics.

\section{REFERENCES}

Abbas AK, Murphy KM, Sher A 1996. Functional diversity of helper T lymphocytes. Nature 383: 787-793.

Akamine EH, Hohman TC, Nigro D, Carvalho MH, de Cassia Tostes R, Fortes ZB 2003. Minalrestat, an aldose reductase inhibitor, corrects the impaired microvascular reactivity in diabetes. J Pharmacol Exp Ther 304: 1236-1242.

Atkinson MA, Maclaren NK 1994. The pathogenesis of insulin-dependent diabetes mellitus. N Engl J Med 331: 14281436.

Barnes PJ 2004. New drugs for asthma. Nat Rev Drug Discov 3: 831-844.

Barreto EO, Carvalho VF, Lagente V, Lugnier C, Cordeiro RS, Martins MA, e Silva PM 2004. Increased levels of cyclic adenosine monophosphate contribute to the hyporesponsiveness of mast cells in alloxan diabetes. Int Immunopharmacol 4: 755-762.

Bell GI, Polonsky KS 2001. Diabetes mellitus and genetically programmed defects in beta-cell function. Nature 414: 788791.

Bottini N, Fontana L 1999. Asthma and diabetes. Lancet 354: 515-516.

Braun CM, Huang SK, Bashian GG, Kagey-Sobotka A, Lichtenstein LM, Essayan DM 1997. Corticosteroid modulation of human, antigen-specific Th1 and Th2 responses. $J$ Allergy Clin Immunol 100: 400-407.

Brownlee M 2001. Biochemistry and molecular cell biology of diabetic complications. Nature 414: 813-820.

Cameron OG, Kronfol Z, Greden JF, Carroll BJ 1984. Hypothalamic-pituitary-adrenocortical activity in patients with diabetes mellitus. Arch Gen Psychiatry 41: 1090-1095.

Cardwell CR, Shields MD, Carson DJ, Patterson CC 2003. A meta-analysis of the association between childhood type 1 diabetes and atopic disease. Diabetes Care 26: 2568-2574.

Carvalho VF, Barreto EO, Diaz BL, Serra MF, Azevedo V, Cordeiro RS, Martins MA, e Silva PM 2003. Systemic anaphylaxis is prevented in alloxan-diabetic rats by a mechanism dependent on glucocorticoids. Eur J Pharmacol 472: 221-227.

Cavalher-Machado SC, de Lima WT, Damazo AS, de Frias Carvalho V, Martins MA, e Silva PM, Sannomiya P 2004. Down-regulation of mast cell activation and airway reactiv- 
ity in diabetic rats: role of insulin. Eur Respir J 24: 552558.

Chan O, Inouye K, Riddell MC, Vranic M, Matthews SG 2003. Diabetes and the hypothalamo-pituitary-adrenal (HPA) axis. Minerva Endocrinol 28: 87-102.

Chan O, Inouye K, Vranic M, Matthews SG 2002. Hyperactivation of the hypothalamo-pituitary-adrenocortical axis in streptozotocin-diabetes is associated with reduced stress responsiveness and decreased pituitary and adrenal sensitivity. Endocrinology 143: 1761-1768.

de Oliveira Barreto E, de Frias Carvalho V, Diaz BL, Balduino A, Cordeiro RS, Martins MA, Rodrigues e Silva PM 2003. Adoptive transfer of mast cells abolishes the inflammatory refractoriness to allergen in diabetic rats. Int Arch Allergy Immunol 131: 212-220.

Dhar HL, Sanyal RK, West GB 1967. Anaphylactic shock and the blood sugar level. J Pharm Pharmacol 19: 699-700.

Diaz B, Barreto E, Cordeiro R, Perretti M, Martins M, Silva P 2001. Enhanced serum glucocorticoid levels mediate the reduction of serosal mast cell numbers in diabetic rats. Life Sci 68: 2925-2932.

Diaz BL, Serra MF, Alves AC, Pires AL, Correa FM, Cordeiro RS, Martins MA, e Silva PM 1996. Alloxan diabetes reduces pleural mast cell numbers and the subsequent eosinophil influx induced by allergen in sensitized rats. Int Arch Allergy Immunol 111: 36-43.

Diaz BL, Serra MF, Barreto EO, Cordeiro RS, Martins MA, e Silva PM 1997. Antigen-induced pleural eosinophilia is suppressed in diabetic rats: role of corticosteroid hormones. Mem Inst Oswaldo Cruz 92 (Suppl II): 219-222.

Douek IF, Leech NJ, Gillmor HA, Bingley PJ, Gale EA 1999. Children with type-1 diabetes and their unaffected siblings have fewer symptoms of asthma. Lancet 353: 1850.

Finotto S, Mekori YA, Metcalfe DD 1997. Glucocorticoids decrease tissue mast cell number by reducing the production of the c-kit ligand, stem cell factor, by resident cells: in vitro and in vivo evidence in murine systems. $J$ Clin Invest 99: 1721-1728.

Fortes ZB, Garcia Leme J, Scivoletto R 1984. Vascular reactivity in diabetes mellitus: possible role of insulin on the endothelial cell. Br J Pharmacol 83: 635-643.

Fortes ZB, Farsky SP, Oliveira MA, Garcia-Leme J 1991. Direct vital microscopic study of defective leukocyte-endothelial interaction in diabetes mellitus. Diabetes 40: 12671273.

Ganley OH 1962. Studies on the prevention of sensitization by Bordetella pertussis in alloxan diabetic mice. Can J Biochem Physiol 40: 1179-1183.

Garcia Leme J, Farsky SP 1993. Hormonal control of inflammatory response. Mediators of Inflammation 2: 181-198.

Garcia-Leme J, Bohm GM, Migliorini RH, de Souza MZ 1974. Possible participation of insulin in the control of vascular permeability. Eur J Pharmacol 29: 298-306.

Garcia Leme J, Hamamura L, Migliorini RH, Leite MP 1973. Experimental diabetes and inflammatory reactions in the rat. Agents Actions 3: 380-381.

Gaulton GN, Schwartz JL, Eardley DD 1985. Assessment of the diabetogenic drugs alloxan and streptozotocin as models for the study of immune defects in diabetic mice. Diabetologia 28: 769-775.

Goldsmith P, McGarity B, Walls AF, Church MK, MillwardSadler GH, Robertson DA 1990. Corticosteroid treatment reduces mast cell numbers in inflammatory bowel disease. Dig Dis Sci 35: 1409-1413.

Hoet JJ, Tripathy BB 1996. Report of the International Workshop on types of Diabetes Peculiar to the Tropics. Diabetes Care 19: 1014.

Isoniemi HM, Ahonen J, Tikkanen MJ, von Willebrand EO, Krogerus L, Eklund BH, Hockerstedt KV, Salmela KE, Hayry PJ 1993. Long-term consequences of different immunosuppressive regimens for renal allografts. Transplantation 55: 494-499.

Klip A, Marette A, Dimitrakoudis D, Ramlal T, Giacca A, Shi ZQ, Vranic M 1992. Effect of diabetes on glucoregulation. From glucose transporters to glucose metabolism in vivo. Diabetes Care 15: 1747-1766.

Larkin JG, Frier BM, Ireland JT 1985. Diabetes mellitus and infection. Postgrad Med J 61: 233-237.

Lima MC, Martins MA, Perez SA, Peixoto JM, Silva PM, Cordeiro RS 1990. Kinetics of pleural exudation and cellular alterations induced by antigen in actively sensitized rats. Braz J Med Biol Res 23: 857-860.

Lima MC, Martins MA, Perez SA, Silva PM, Cordeiro RS, Vargaftig BB 1991. Effect of azelastine on platelet-activating factor and antigen-induced pleurisy in rats. Eur $J$ Pharmacol 197: 201-207.

Ludvik B, Clodi M, Kautzky-Willer A, Capek M, Hartter E, Pacini G, Prager R 1993. Effect of dexamethasone on insulin sensitivity, islet amyloid polypeptide and insulin secretion in humans. Diabetologia 36: 84-87.

Lukens FDW 1948. Alloxan diabetes. Physiol Rev 28: 304-328.

Meehan WP, Leedom LJ, Henry JP 1988. Diabetes mellitus, adrenal function and the defeat response. Acta Physiol Scand 571 (Suppl.): 117-128.

Mello SB, Farsky SH, Sannomiya P, Garcia-Leme J 1992. Inhibition of neutrophil chemotaxis and chemokinesis associated with a plasma protein in aging rats: selective depression of cell responses mediated by complement-derived chemoattractants. J Leukoc Biol 51: 46-52.

Metcalfe DD, Baram D, Mekori YA 1997. Mast cells. Physiol Rev 77: 1033-1079.

Mirel DB, Valdes AM, Lazzeroni LC, Reynolds RL, Erlich HA, Noble JA 2002. Association of IL4R haplotypes with type 1 diabetes. Diabetes 51: 3336-3341.

Mowat A, Baum J 1971. Chemotaxis of polymorphonuclear leukocytes from patients with diabetes mellitus. $N$ Engl J Med 284: 621-627.

Muir A, Schatz DA, Maclaren NK 1992. The pathogenesis, prediction, and prevention of insulin-dependent diabetes mellitus. Endocrinol Metab Clin North Am 21: 199-219.

Olesen AB, Juul S, Birkebaek N, Thestrup-Pedersen K 2001. Association between atopic dermatitis and insulin-dependent diabetes mellitus: a case-control study. Lancet 357: 1749-1752. 
Pipkorn U, Hammarlund A, Enerback L 1989. Prolonged treatment with topical glucocorticoids results in an inhibition of the allergen-induced weal-and-flare response and a reduction in skin mast cell numbers and histamine content. Clin Exp Allergy 19: 19-25.

Ptak W, Rewicka M, Strzyzewska J, Kollat M 1983. Alleviation of IgE-mediated immune reactions in hypoinsulinaemic and hyperglycaemic mice. Clin Exp Immunol 52: 54-60.

Quan N, Ho E, La W, Tsai YH, Bray T 2001. Administration of NF-kappaB decoy inhibits pancreatic activation of NFkappaB and prevents diabetogenesis by alloxan in mice. Faseb J 15: 1616-1618.

Rapoport MJ, Jaramillo A, Zipris D, Lazarus AH, Serreze DV, Leiter EH, Cyopick P, Danska JS, Delovitch TL 1993. Interleukin 4 reverses $\mathrm{T}$ cell proliferative unresponsiveness and prevents the onset of diabetes in nonobese diabetic mice. J Exp Med 178: 87-99.

Rayfield EJ, Ault MJ, Keusch GT, Brothers MJ, Nechemias C, Smith H 1982. Infection and diabetes: the case for glucose control. Am J Med 72: 439-450.

Rerup CC 1970. Drugs producing diabetes through damage of the insulin secreting cells. Pharmacol Rev 22: 485-518.

Romagnani S 1991. Human TH1 and TH2 subsets: doubt no more. Immunol Today 12: 256-257.

Roy M, Collier B, Roy A 1990. Hypothalamic-pituitary-adrenal axis dysregulation among diabetic outpatients. Psychiatry Res 31: 31-37.

Roy MS, Roy A, Brown S 1998. Increased urinary-free cortisol outputs in diabetic patients. J Diabetes Complications 12: 24-27.

Schleimer RP 1993. An overview of glucocorticoid anti-inflammatory actions. Eur J Clin Pharmacol 45 (Suppl 1): S3-7; discussion S43-44.
Silva PMR, Martins MA, Lima MC, Alves AC, Diaz BL, Cordeiro RS 1992. Pharmacological modulation of the late eosinophilia induced by antigen in actively sensitized rats. Int Arch Allergy Immunol 98: 355-360.

Strauss DS 1984. Growth stimulatory actions of insulin in vitro and in vivo. Endocrine Review 5: 356-369.

Taskinen MR, Lahdenpera S, Syvanne M 1996. New insights into lipid metabolism in non-insulin-dependent diabetes mellitus. Ann Med 28: 335-340.

Tinkelman D, King S 1979. Severe asthma and volatile diabetes mellitus in the same patient: a treatment dilemma. J Allergy Clin Immunol 64: 223-226.

Tisch R, McDevitt H 1996. Insulin-dependent diabetes mellitus. Cell 85: 291-297.

Vianna EO, Garcia-Leme J 1995. Allergen-induced airway inflammation in rats. Role of insulin. Am J Respir Crit Care Med 151: 809-814.

Vlassara H, Brownlee M, Cerami A 1984. Accumulation of diabetic rat peripheral nerve myelin by macrophages increases with the presence of advanced glycosylation endproducts. J Exp Med 160: 197-207.

Wertman KF, Henney MR 1962. The effects of alloxan diabetes on phagocytosis and susceptibility to infection. $J$ Immunol 89: 314-317.

Wood SC, Rao TD, Frey AB 1999. Multidose streptozotocin induction of diabetes in BALB/cBy mice induces a $\mathrm{T}$ cell proliferation defect in thymocytes which is reversible by interleukin-4. Cell Immunol 192: 1-12.

Yabe-Nishimura C 1998. Aldose reductase in glucose toxicity: a potential target for the prevention of diabetic complications. Pharmacol Rev 50: 21-33.

Zimmet P, Alberti KG, Shaw J 2001. Global and societal implications of the diabetes epidemic. Nature 414: 782-787. 
